\title{
First-quarter biotech job picture
}

\section{Michael Francisco}

\begin{abstract}
The first quarter of 2018 saw mixed signals from the pharma and biotech sectors regarding employment numbers. In early January, Allergan announced that it would terminate over 1,000 employees and eliminate about 400 open positions as part of a plan to reduce costs to save up to $\$ 400$ million in 2018 operating expenses, as it prepares for potential generic competition to Restasis (cyclosporine), which generated $\$ 1.5$ billion last year for the Dublin-based drugmaker. The job cuts will come from commercial and other functions.
\end{abstract}

\begin{tabular}{|c|c|c|c|c|}
\hline \multirow[b]{2}{*}{ Company ${ }^{a}$} & \multirow{2}{*}{$\begin{array}{l}\text { Number of } \\
\text { employees }\end{array}$} & \multicolumn{3}{|c|}{ Number of advertised openings ${ }^{b}$} \\
\hline & & Monster & LinkedIn & Naturejobs \\
\hline Shire & 23,906 & 802 & 790 & 0 \\
\hline Monsanto & 20,800 & $1,000+$ & 203 & 0 \\
\hline Amgen & 19,200 & 350 & 592 & 0 \\
\hline bioMérieux & 9,335 & 0 & 32 & 0 \\
\hline Gilead Sciences & 9,000 & 15 & 366 & 0 \\
\hline Biocon & 8,234 & 0 & 0 & 2 \\
\hline Biogen & 7,400 & 144 & 281 & 0 \\
\hline IDEXX Laboratories & 7,365 & 137 & 196 & 0 \\
\hline Celgene & 7,132 & 155 & 262 & 0 \\
\hline Novozymes & 6,295 & 0 & 2 & 0 \\
\hline Opko Health & 6,041 & 4 & 0 & 0 \\
\hline Illumina & 5,500 & 61 & 265 & 0 \\
\hline $\begin{array}{l}\text { Regeneron } \\
\text { Pharmaceuticals }\end{array}$ & 5,400 & 332 & 613 & 0 \\
\hline Endo Pharmaceuticals & 4,894 & 93 & 32 & 0 \\
\hline $\begin{array}{l}\text { Alexion } \\
\text { Pharmaceuticals }\end{array}$ & 3,121 & 102 & 207 & 0 \\
\hline AMRI & 3,085 & 0 & 69 & 0 \\
\hline Actelion & 2,624 & 2 & 17 & 0 \\
\hline Biotest & 2,527 & 0 & 66 & 0 \\
\hline $\begin{array}{l}\text { BioMarin } \\
\text { Pharmaceutical }\end{array}$ & 2,293 & 0 & 85 & 0 \\
\hline Myriad Genetics & 2,206 & 123 & 140 & 0 \\
\hline Vertex Pharmaceuticals & 2,150 & 156 & 152 & 0 \\
\hline Alkermes & 1,750 & 494 & 464 & 0 \\
\hline CK Life Sciences & 1,747 & 0 & 0 & 0 \\
\hline GenScript Biotech & 1,592 & 0 & 2 & 0 \\
\hline $\begin{array}{l}\text { Amphastar } \\
\text { Pharmaceuticals }\end{array}$ & 1,541 & 0 & 0 & 0 \\
\hline Total & & 3,970 & 4,836 & 2 \\
\hline
\end{tabular}

Also in January, Pfizer announced it will terminate its discovery and early-development neuroscience programs, consisting of preclinical and phase 1/2 programs primarily focused on Alzheimer's and Parkinson's disease, resulting in 300 layoffs at its Cambridge and Andover, Massachusetts, and Groton, Connecticut sites. And in February, Achillion Pharmaceuticals said it would reduce headcount by about $20 \%$ to about 70 employees to save $\$ 10$ million.

Paris-based Sanofi announced 400 job cuts in its United States diabetes and cardiovascular sales organization, and its subsidiary Genzyme said it will let go of 130 workers at its Allston Landing biomanufacturing facility in Boston. The change is associated with the outsourcing of certain aspects of the production process and improvements in technology and operations, according to a company spokesperson.

Amicus Therapeutics of Cranbury, New Jersey plans to build a \$200-million biologics facility in the US for its Pompe disease program. The company said various locations outside the US had previously been under consideration.

Finally, Darmstadt, Germany-based Merck KGaA said it will invest $\$ 40$ million in two new manufacturing and distribution centers in Songdo, South Korea, and Mumbai, India, and the completion of its biosimilar-capable manufacturing center in Wuxi, China. All three centers expect to be completed over the next two years.

Advertised biotech and pharma sector jobs in the job databases tracked by Nature Biotechnology during the first quarter of 2018 are shown in Tables 1 and 2.

\begin{tabular}{|c|c|c|c|c|}
\hline \multirow[b]{2}{*}{ Company ${ }^{a}$} & \multirow{2}{*}{$\begin{array}{l}\text { Number of } \\
\text { employees }\end{array}$} & \multicolumn{3}{|c|}{ Number of advertised openings ${ }^{b}$} \\
\hline & & Monster & Linkedln & Naturejobs \\
\hline Novartis & 133,413 & $1,000+$ & 417 & 0 \\
\hline Johnson \& Johnson & 126,500 & $1,000+$ & 955 & 0 \\
\hline Sanofi & 113,496 & 19 & 597 & 1 \\
\hline GlaxoSmithKline & 98,702 & 3 & 242 & 0 \\
\hline Roche & 88,509 & 391 & 264 & 6 \\
\hline Pfizer & 78,300 & 23 & 579 & 0 \\
\hline Abbott Laboratories & 77,000 & 49 & 161 & 0 \\
\hline Merck \& Co. & 70,000 & 17 & 49 & 5 \\
\hline AstraZeneca & 57,500 & 5 & 57 & 86 \\
\hline Teva Pharmaceutical & 43,009 & 0 & 178 & 0 \\
\hline Total & & 2,507 & 3,499 & 98 \\
\hline
\end{tabular}

a Data obtained from Statista. ${ }^{b}$ As searched on Monster.com, LinkedIn.com and Naturejobs.com, 11 April 2018. Jobs may overlap. 